\title{
Pengaruh Takaran Arang Sekam dan Pupuk Kandang Sapi Terhadap Pertumbuhan dan Hasil Kacang Hijau (Vigna radiata, L.)
}

\author{
Maria Ancila Naimnule ${ }^{\text {a }}$ \\ ${ }^{a}$ Fakultas Pertanian, Universitas Timor, Kefamenanu, TTU - NTT, Indonesia.
}

\section{Article Info}

\section{Article history:}

Received 12 Maret 2016

Received in revised form 28 Juni 2016

Accepted 24 September 2016

Keywords:

Arang Sekam

Pupuk Kandang Sapi

Kacang Hijau

\begin{abstract}
Abstrak
Penelitian ini bertujuan untuk mengetahui pengaruh takaran arang sekam dan takaran pupuk kandang sapi terhadap pertumbuhan dan hasi kacang hijau. Percobaan pot telah dilakukan di Kebun Fakultas Pertanian Universitas Timor dengan menggunakan rancangan acak lengkap faktorial $3 \times 3$ yang terdiri dari 3 pot tanaman sampel dan 2 pot tanaman korban. Faktor yang diteliti adalah takaran arang sekam yang terdiri dari 3 aras yaitu kontrol atau 0, 5, dan 10 t/ha. Faktor kedua adalah takaran pupuk kandang sapi yang terdiri dari 3 aras yaitu kontol atau 0,5, dan 10 t/ha. Hasil penelitian menunjukkan interaksi antara takaran arang sekam dan pupuk kandang sapi pada parameter $\mathrm{pH}$ tanah, daya hantar listrik, tinggi tanaman 14 dan 42 hari, jumlah daun 42 hari setelah tanam, panjang akar, jumlah polong, jumlah biji per tanaman, berat segar biji, berat segar akar, berat kering akar, berat segar berangkasan, berat kering berangkasan, indeks panen. Hasil tertinggi diperoleh dari pemberian arang sekam 5 t/ha dan pupuk kandang sapi 5 t/ha. @2016 dipublikasikan oleh Savana Cendana.
\end{abstract}

\section{Pendahuluan}

Kacang hijau termasuk bahan pangan penting karena nutrisi yang terkandung di dalam bijinya dapat mensubtitusi fungsi daging (Duke, 1991). Kacang hijau memiliki kelebihan ditinjau dari segi agronomi dan ekonomis, seperti lebih tahan kekeringan, serangan hama dan penyakit sedikit, dapat dipanen pada umur 55-60 hari, dapat ditanam pada tanah yang kurang subur, dan cara budidaya mudah (Sunantara, 2000). Namun demikian, produksi kacang hijau di Indonesia masih rendah dan belum mampu memenuhi kebutuhan domestik.

Menurut Direktorat Budidaya Aneka Kacang dan Umbi, Ditjen Tanaman Pangan (2012), produksi kacang hijau cenderung terus menurun, sehingga untuk kebutuhan kacang hijau dipenuhi dari impor dengan rata-rata sebesar \pm 29.443 ton/tahun. Kenyataan yang sama terjadi di wilayah Nusa Tenggara Timur. Data BPS NTT (2015) menunjukkan bahwa produksi kacang hijau pada tahun 2012 sebesar 11.478 ton menurun menjadi 10.139 ton pada tahun 2013 Oleh karena itu, perlu diupayakan peningkatan produktifitas kacang hijau dengan teknik budidaya kacang hijau, di antaranya dengan pemberian arang sekam dan pupuk kandang sapi.

Arang sekam merupakan media tanam yang praktis digunakan karena tidak perlu disterilisasi, hal ini disebabkan mikroba patogen telah mati selama proses pembakaran. Arang sekam mengandung unsur hara $\mathrm{N} 0,3 \%, \mathrm{P}_{2} \mathrm{O}_{5} 15 \%, \mathrm{~K}_{2} \mathrm{O}$ $31 \%$, dan beberapa unsur hara lainnya dengan $\mathrm{pH} 6,8$. Selain hal tersebut, arang sekam juga memiliki kemampuan menahan air tinggi, bertekstur remah, siklus udara dan KTK tinggi, dan dapat mengabsosbsi sinar matahari dengan efektif (Fahmi, 2013; Soemeinaboedhy dan Tejowulan, 2007). Di dalam tanah, arang sekam bekerja dengan cara memperbaiki struktur fisik, kimia dan biologi tanah. Arang sekam dapat meningkatkan porositas tanah sehingga tanah menjad gembur sekaligus juga meningkatkan kemampuan tanah menyerap air. Arang sekam mempunyai sifat yang mudah mengikat air, tidak mudah menggumpal, harganya relatif murah, mempunyai porositas yang baik, ringan, steril dan bahannya mudah didapat (Prihmantoro, 2003).

Keunggulan arang sekam yang dapat mengikat air dan unsur hara akan berdampak positif dalam penggunaannya dengan pupuk kandang karena beberapa jenis unsur hara dalam pupuk kandang yang mudah hilang dapat diikat oleh arang sekam. Dengan demikian pemanfaatan unsur hara oleh akar tanaman menjadi lebih mudah, sehingga pertumbuhan dan hasil tanaman meningkat. Penelitian Syahid et al. (2013) membuktikan bahwa pemberian pupuk kandang ayam atau kambing dosis $20 \mathrm{t} / \mathrm{ha}$ dengan arang sekam padi dosis $10 \mathrm{t} / \mathrm{ha}$ memberikan pertambahan tinggi dan jumlah daun paling banyak serta hasi tamanan paling optimal.

Pupuk kandang sapi dapat menambah ketersediaan unsur-unsur hara bagi tanaman, juga mengembangkan kehidupan mikroorganisme di dalam tanah Mikroorganisme berperan mengubah seresah dan sisa-sisa tanaman menjadi humus, senyawa-senyawa tertentu disintesa menjadi bahan-bahan yang berguna bagi tanaman (Lingga, 1991).

Pupuk kandang sapi memiliki keunggulan dibanding pupuk kandang lainnya yaitu mempunyai kadar serat yang tinggi seperti selulosa, menyediakan unsur hara makro dan mikro bagi tanaman, serta memperbaiki daya serap air pada tanah (Hartatik dan Widowati, 2010)

Manfaat arang sekam dan pupuk kandang sapi yang mampu memperbaiki kondisi fisik, kimia dan biologi tanah tersebut tentu dapat digunakan pula dalam meningkatkan pertumbuhan dan hasil kacang hijau di lahan kering. Kombinasi arang sekam dan pupuk kandang sapi yang mampu menjaga kelembaban tanah dan menyediakan unsur hara diharapkan dapat memperbaiki kondisi tanah $\mathrm{di}$ lahan kering yang rendah ketersediaan unsur hara dan air. Oleh karena itu perlu dilakukan penelitian tentang "Pengaruh Takaran Arang Sekam dan Pupuk Kandang Sapi Terhadap Pertumbuhan dan Hasil Kacang Hijau”.

\section{Metode}

Penelitian telah dilaksanakan pada Desember 2015 sampai Februari 2016 di kebun percobaan Fakultas Pertanian, Universitas Timor, Kelurahan Sasi, Kecamatan Kota Kefamenanu, Kabupaten TTU. Rancangan yang digunakan dalam penelitian ini adalah rancangan acak lengkap pola faktorial 3 x 3 yang diulang 3 kali dengan 3 pot tanaman sampel dan 2 pot tanaman korban. Faktor pertama adalah takaran arang sekam (A) yang terdiri dari 3 aras yaitu tanpa arang sekam/ kontrol $\left(\mathrm{a}_{0}\right), 5 \mathrm{t} / \mathrm{ha}\left(\mathrm{a}_{1}\right), 10 \mathrm{t} / \mathrm{ha}\left(\mathrm{a}_{3}\right)$. Faktor kedua takaran pupuk kandang sapi $(\mathrm{K})$ yang terdiri dari 3 aras yaknitanpa pupuk kandang sapi/kontrol $\left(\mathrm{k}_{0}\right), 5$ $\mathrm{t} / \mathrm{ha}\left(\mathrm{k}_{1}\right) 10 \mathrm{t} / \mathrm{ha}\left(\mathrm{k}_{2}\right)$

Data hasil pengamatan kemudian dianalisis dengan menggunakan sidik ragam (Anova) rancangan acak lengkap. Rata-rata perlakuan selanjutnya diuj lanjut dengan menggunakan Tukey test atau HSD dengan tingkat signifikasi 5\% sesuai petunjuk Gomez dan Gomez, (1995). Analisis data menggunakan program SAS 9.1.

\section{Hasil dan Pembahasan}

3.1 Tinggi Tanaman

Hasil sidik ragam (Anova) menunjukkan bahwa tinggi tanaman pada pengamatan 14 HST terjadi interaksi, pengamatan 28 HST tidak terjadi interaksi, dan pada pengamatan 42 HST kembali terjadi interaksi antara takaran arang sekam dan pupuk kandang sapi. Hasil uji lanjut menunjukkan bahwa pemberian arangsekam dan pukan sapi menyebabkan tanaman lebih tinggi dibandingkan dengan kontrol.

Tabel 1. Tinggi tanaman $(\mathrm{cm})$

\begin{tabular}{ccllcc} 
Waktu & Takaran arang & \multicolumn{3}{c}{ Takaran pupuk kandang Sapi (t/ha) } & \multirow{2}{*}{ Rerata } \\
\cline { 3 - 5 } Pengamatan & sekam (t/ha) & 0 & 5 & 10 & \\
\hline \multirow{3}{*}{14 HST } & 0 & $16,13 \mathrm{c}$ & $19,53 \mathrm{ab}$ & $20,16 \mathrm{a}$ & 18,61 \\
& 5 & $18,43 \mathrm{abc}$ & $18,66 \mathrm{abc}$ & $18,06 \mathrm{abc}$ & 18,38 \\
& 10 & $17,16 \mathrm{bc}$ & $19,13 \mathrm{ab}$ & $18,16 \mathrm{abc}$ & 18,15 \\
\cline { 2 - 5 } & Rerata & 17,24 & 19,11 & 18,80 & $(+)$ \\
\hline \multirow{3}{*}{$28 \mathrm{HST}$} & 0 & 18,80 & 22,40 & 23,26 & $21,48 \mathrm{a}$ \\
& 5 & 21,26 & 21,00 & 21,80 & $21,68 \mathrm{a}$ \\
& 10 & 21,43 & 22,40 & 22,86 & $22,23 \mathrm{a}$ \\
\hline \multirow{4}{*}{$42 \mathrm{HST}$} & Rerata & $20,50 \mathrm{~b}$ & $22,26 \mathrm{a}$ & $22,64 \mathrm{a}$ & $(-)$ \\
& 0 & $28,50 \mathrm{~b}$ & $32,10 \mathrm{ab}$ & $36,53 \mathrm{a}$ & 32,37 \\
& 5 & $34,36 \mathrm{a}$ & $32,56 \mathrm{ab}$ & $35,66 \mathrm{a}$ & 34,20 \\
& 10 & $34,46 \mathrm{a}$ & $37,30 \mathrm{a}$ & $34,70 \mathrm{a}$ & 35,48 \\
\hline \multirow{2}{*}{ Kennnn} & Rerata & 32,44 & 33,98 & 35,63 & $(+)$ \\
\hline
\end{tabular}

Keterangan: Angka yang diikuti dengan huruf yang sama pada kolom atau baris yang sama tidak berbeda nyata menurut uji Tukey $\alpha$ 5\%. (-): Tidak terjadi interaksi antara fakto

\subsection{Diameter batang}

Hasil sidik ragam (Anova) menunjukkan tidak terjadi pengaruh interaksi antara takaran arang sekam dan pupuk kandang sapi terhadap diameter batang.

Tabel 2. Diameter batang $(\mathrm{mm})$

\begin{tabular}{|c|c|c|c|c|c|}
\hline \multirow{2}{*}{$\begin{array}{c}\text { Waktu } \\
\text { Pengamatan }\end{array}$} & \multirow{2}{*}{$\begin{array}{l}\text { Takaran Arang } \\
\text { sekam (t/ha) }\end{array}$} & \multicolumn{3}{|c|}{$\begin{array}{c}\text { Takaran Pupuk kandang Sapi } \\
(\mathrm{t} / \mathrm{ha})\end{array}$} & \multirow[t]{2}{*}{ Rerat } \\
\hline & & 0 & 5 & 10 & \\
\hline \multirow{4}{*}{14 HST } & 0 & 2,73 & 3,10 & 2,96 & $2,93 \mathrm{a}$ \\
\hline & 5 & 2,86 & 3,13 & 3,00 & $3,00 \mathrm{a}$ \\
\hline & 10 & 2,76 & 2,86 & 2,93 & $2,85 \mathrm{a}$ \\
\hline & Rerata & $2,78 \mathrm{a}$ & $3,03 \mathrm{a}$ & $3,96 \mathrm{a}$ & $(-)$ \\
\hline \multirow{4}{*}{$28 \mathrm{HST}$} & 0 & 3,83 & 4,70 & 4,50 & $4,34 \mathrm{a}$ \\
\hline & 5 & 4,33 & 4,50 & 4,46 & $4,43 \mathrm{a}$ \\
\hline & 10 & 4,86 & 4,46 & 4,30 & $4,54 \mathrm{a}$ \\
\hline & Rerata & $4,34 \mathrm{a}$ & $4,55 \mathrm{a}$ & $4,42 \mathrm{a}$ & $(-)$ \\
\hline \multirow{4}{*}{$42 \mathrm{HST}$} & 0 & 5,60 & 7,90 & 7,50 & $6,66 \mathrm{~b}$ \\
\hline & 5 & 7,03 & 7,56 & 7,83 & $7,47 \mathrm{a}$ \\
\hline & 10 & 7,23 & 7,46 & 7,36 & $7,35 \mathrm{a}$ \\
\hline & Rerata & $6,62 \mathrm{~b}$ & $7,31 \mathrm{a}$ & $7,56 \mathrm{a}$ & $(-)$ \\
\hline
\end{tabular}

Keterangan: Angka yang diikuti dengan huruf yang sama pada kolom atau baris yang sama tidak berbeda nyata menurut uji Tukey $\alpha 5 \%$. (-): Tidak terjadi interaksi antara faktor 
Hasil uji lanjut menunjukkan bahwa pengamatan 14 HST dan 28 HST tidak terjadi perbedaan secara nyata tetapi pada pengamatan 42 HST ada perbedaan nyata antara tanaman yang diberi arang sekam dan pukan sapi dibandingkan dengan kontrol.

\subsection{Jumlah daun}

Hasil sidik ragam (Anova) menunjukkan terjadi pengaruh interaksi antara takaran arang sekam dan pupuk kandang sapi terhadap diameter batang pada waktu pengamatan 42 HST. Hasil uji lanjut menunjukkan bahwa untuk pengamatan 14 dan 28 HST tak ada beda nyata antar perlakuan, dan pengamatan 42 HST ada beda nyata antar pot perlakuan kombinasi.

Tabel 3. Jumlah daun (helai)

\begin{tabular}{|c|c|c|c|c|c|}
\hline \multirow{2}{*}{$\begin{array}{c}\text { Waktu } \\
\text { Pengamatan }\end{array}$} & \multirow{2}{*}{$\begin{array}{c}\text { Takaran Arang } \\
\text { Sekam (t/ha) }\end{array}$} & \multicolumn{3}{|c|}{$\begin{array}{c}\text { Takaran Pupuk kandang Sapi } \\
(\mathrm{t} / \mathrm{ha})\end{array}$} & \multirow[t]{2}{*}{ Rerata } \\
\hline & & 0 & 5 & 10 & \\
\hline \multirow{4}{*}{14 HST } & 0 & 10,00 & 10,00 & 9,00 & $9,66 \mathrm{a}$ \\
\hline & 5 & 10,00 & 10,00 & 7,00 & $9,00 \mathrm{a}$ \\
\hline & 10 & 9,00 & 9,00 & 10,00 & $9,33 \mathrm{a}$ \\
\hline & Rerata & $9,66 \mathrm{a}$ & $9,66 \mathrm{a}$ & $8,66 \mathrm{a}$ & $(-)$ \\
\hline \multirow{4}{*}{$28 \mathrm{HST}$} & 0 & 16,66 & 13,33 & 13,66 & $12,88 \mathrm{a}$ \\
\hline & 5 & 15,00 & 15,00 & 14,66 & $14,88 \mathrm{a}$ \\
\hline & 10 & 15,00 & 15,00 & 15,66 & $15,22 \mathrm{a}$ \\
\hline & Rerata & $13,88 \mathrm{a}$ & $14,44 \mathrm{a}$ & $14,66 \mathrm{a}$ & $(-)$ \\
\hline \multirow{4}{*}{$42 \mathrm{HST}$} & 0 & $19,33 c$ & $27,66 \mathrm{ab}$ & $27,66 \mathrm{ab}$ & 24,88 \\
\hline & 5 & $26,66 \mathrm{ab}$ & $29,33 \mathrm{a}$ & $27,33 \mathrm{ab}$ & 27,77 \\
\hline & 10 & $24,66 \mathrm{~b}$ & $27,33 \mathrm{ab}$ & $27,66 \mathrm{ab}$ & 26,55 \\
\hline & Rerata & 23,55 & 28,11 & 27,55 & $(+)$ \\
\hline
\end{tabular}

\subsection{Luas daun}

Hasil sidik ragam (Anova) menunjukan bahwa tidak terjadi interaksi antara takaran arang sekam dan pupuk kandang sapi terhadap luas daun. Hasil uji selanjutnya menunjukkan bahwa tidak ada perbedaan antara tiap perlakuan.

Tabel 4. Luas daun $\left(\mathrm{cm}^{2}\right)$

\begin{tabular}{|c|c|c|c|c|}
\hline \multirow{2}{*}{$\begin{array}{c}\text { Takaran Arang } \\
\text { sekam }(\mathrm{t} / \mathrm{ha})\end{array}$} & \multicolumn{3}{|c|}{ Takaran Pupuk kandang Sapi (t/ha) } & \multirow{2}{*}{ Rerata } \\
\hline & 0 & 5 & 10 & \\
\hline 0 & 232,25 & 249,79 & 321,61 & $267,88 \mathrm{a}$ \\
\hline 5 & 301,34 & 381,21 & 388,25 & $356,93 a$ \\
\hline 10 & 378,36 & 371,26 & 277,30 & $342,31 \mathrm{a}$ \\
\hline Rerata & $303,98 \mathrm{a}$ & $334,09 a$ & $329,05 \mathrm{a}$ & $(-)$ \\
\hline
\end{tabular}

\subsection{Panjang akar}

Hasil sidik ragam (Anova) menunjukan bahwa terjadi pengaruh interaksi antara takaran arang sekam dan pupuk kandang sapi terhadap panjang akar. Hasil uji lanjut menunjukkan bahwa ada perbedaan secara nyata.

\section{Tabel 5. Panjang akar $(\mathrm{cm})$}

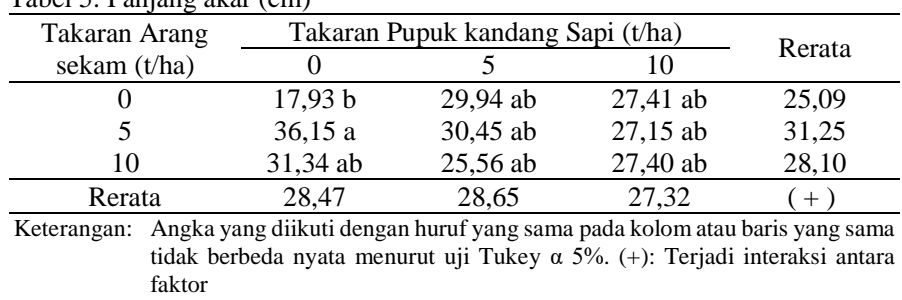

\subsection{Jumlah bintil akar}

Hasil sidik ragam (Anova) menunjukan bahwa tidak terjadi pengaruh interaksi antara takaran arang sekam dan pupuk kandang sapi terhadap bintil akar. Dapat dilihat bahwa hasil uji selanjutnya menunjukkan bahwa pada perlakuan takaran arang sekam tidak ada beda nyata, tetapi untuk perlakuan takaran pupuk kandang sapi ada perbedaan secara nyata.

Tabel 6. Jumlah bintil akar (bintil)

\begin{tabular}{ccccc}
\hline Takaran Arang & \multicolumn{2}{c}{ Takaran Pupuk kandang Sapi (t/ha) } & \multirow{2}{*}{ Rerata } \\
\cline { 2 - 4 } sekam (t/ha) & 0 & 5 & 10 & \\
\hline 0 & 80,00 & 98,50 & 157,00 & $111,83 \mathrm{a}$ \\
5 & 82,00 & 124,50 & 79,00 & $95,16 \mathrm{a}$ \\
10 & 93,50 & 161,50 & 126,00 & $127,00 \mathrm{a}$ \\
\hline Rerata & $85,16 \mathrm{~b}$ & $128,16 \mathrm{a}$ & $120,66 \mathrm{ab}$ & $(-)$ \\
\hline
\end{tabular}

Keterangan: Angka yang diikuti dengan huruf yang sama pada kolom atau baris yang sam tidak berbeda nyata menurut uji Tukey $\alpha 5 \%$. (-): Tidak terjadi interaksi antara faktor

\subsection{Jumlah Polong}

Hasil sidik ragam (Anova) menunjukkan tidak terjadi pengaruh interaksi antara takaran arang sekam dan pupuk kandang sapi terhadap jumlah polong Hasil uji selanjutnya menunjukkan bahwa, tak ada beda nyata antar perlakuan.

Tabel 7. Jumlah polong (polong)

\begin{tabular}{ccccc}
\hline Takaran Arang & \multicolumn{2}{c}{ Takaran Pupuk kandang Sapi (t/ha) } & \multirow{2}{*}{ Rerata } \\
\cline { 2 - 4 } sekam (t/ha) & 0 & 5 & 10 & \\
\hline 0 & 3,77 & 3,55 & 4,66 & $4,00 \mathrm{a}$ \\
5 & 4,44 & 5,77 & 4,44 & $4,88 \mathrm{a}$ \\
10 & 4,66 & 3,88 & $5,11 \mathrm{a}$ & $4,55 \mathrm{a}$ \\
\hline Rerata & $4,29 \mathrm{a}$ & $4,40 \mathrm{a}$ & $4,74 \mathrm{a}$ & $(-)$ \\
\hline
\end{tabular}

Keterangan: Angka yang diikuti dengan huruf yang sama pada kolom atau baris yang sama tidak berbeda nyata menurut uji Tukey $\alpha$ 5\%. (+): terjadi interaksi antara faktor

\subsection{Panjang Polong}

Hasil sidik ragam (Anova) menunjukkan bahwa tidak terjadi pengaruh interaksi antara takaran arang sekam dan pupuk kandang sapi terhadap panjang polong. Hasil uji selanjutnya menunjukkan tidak ada perbedaan secara nyata antar perlakuan

Tabel 8. Panjang polong (cm)

\begin{tabular}{ccccc}
\hline Takaran Arang & \multicolumn{2}{c}{ Takaran Pupuk kandang Sapi (t/ha) } & \multirow{2}{*}{ Rerata } \\
\cline { 2 - 4 } sekam (t/ha) & 0 & 5 & 10 & \\
\hline 0 & 7,98 & 8,86 & 9,02 & $8,62 \mathrm{a}$ \\
5 & 8,34 & 8,54 & 8,94 & $8,60 \mathrm{a}$ \\
10 & 8,58 & 8,86 & 9,33 & $8,93 \mathrm{a}$ \\
\hline Rerata & $8,30 \mathrm{a}$ & $8,75 \mathrm{a}$ & $9,10 \mathrm{a}$ & $(-)$ \\
\hline Keterangan: & Angka yang diikuti dengan huruf yang sama pada kolom atau baris yang sama \\
& \multicolumn{2}{l}{ tidak berbeda nyata menurut uji Tukey $\alpha$} & $5 \%$. (-): Tidak terjadi interaksi
\end{tabular}
antara faktor

\subsection{Jumlah Biji Per Polong}

Hasil sidik ragam (ANOVA) menunjukkan bahwa jumlah biji per polong tidak terjadi interaksi antara takaran arang sekam dan takaran pupuk kandang. Selanjutnya pada hasil uji lanjut dapat dilihat untuk perlakuan takaran arang sekam ada beda nyata, sedang perlakuan pupuk kandang sapi tak beda nyata.

Tabel 9. Jumlah biji per polong (biji)

\begin{tabular}{ccccc}
\hline Takaran Arang & \multicolumn{2}{c}{ Takaran Pupuk kandang Sapi (t/ha) } & \multirow{2}{*}{ Rerata } \\
\cline { 2 - 4 } sekam (t/ha) & 0 & 5 & 10 & \\
\hline 0 & 4,62 & 7,66 & 7,05 & $6,44 \mathrm{~b}$ \\
5 & 7,59 & 7,28 & 6,71 & $7,19 \mathrm{ab}$ \\
10 & 8,03 & 8,34 & 7,44 & $7,94 \mathrm{a}$ \\
\hline Rerata & $6,75 \mathrm{a}$ & $7,76 \mathrm{a}$ & $7,06 \mathrm{a}$ & $(-)$
\end{tabular}

Keterangan: Angka yang diikuti dengan huruf yang sama pada kolom atau baris yang sama tidak berbeda nyata menurut uji Tukey a 5\%. (-): Tidak terjadi interaksi antara faktor

\subsection{Jumlah Biji Per Tanaman}

Hasil sidik ragam (ANOVA) menunjukkan bahwa pada jumlah biji per tanaman terjadi interaksi antara takaran arang sekam dan takaran pupuk kandang. Selanjutnya pada hasil uji lanjutnya dapat dilihat bahwa pada pot perlakuan kombinasi terjadi perbedaan secara nyata. Jumlah biji paling banyak pada pot perlakuan kombinasi arang sekam 5 t/ha dan pupuk kandang sapi 5 t/ha.

Tabel 10. Jumlah biji per tanaman (biji)

\begin{tabular}{ccccc}
\hline Takaran Arang & \multicolumn{2}{c}{ Takaran Pupuk kandang Sapi (t/ha) } & \multirow{2}{*}{ Rerata } \\
\cline { 2 - 4 } sekam (t/ha) & 0 & 5 & 10 & \\
\hline 0 & $16,88 \mathrm{~b}$ & $27,44 \mathrm{ab}$ & $32,44 \mathrm{ab}$ & 25,59 \\
5 & $32,55 \mathrm{ab}$ & $41,88 \mathrm{a}$ & $30,88 \mathrm{ab}$ & 35,11 \\
10 & $36,77 \mathrm{a}$ & $32,22 \mathrm{ab}$ & $37,66 \mathrm{a}$ & 35,55 \\
\hline Rerata & 28,74 & 33,85 & 33,66 & $(+)$
\end{tabular}

Keterangan: Angka yang diikuti dengan huruf yang sama pada kolom atau baris yang sama tidak berbeda nyata menurut uji Tukey $\alpha 5 \%$. (+): Terjadi interaksi antara faktor

\subsection{Berat Segar Biji Per Tanaman}

Hasil sidik ragam (Anova) menunjukan bahwa terjadi pengaruh interaksi antara takaran arang sekam dan pupuk kandang sapi terhadap berat segar biji per tanaman. Hasil uji selanjutnya menunjukkan bahwa pada pot perlakuan kombinasi ada beda nyata.

Tabel 11. Berat segar biji per tanaman $(\mathrm{g})$

\begin{tabular}{ccccc}
\hline Takaran Arang & \multicolumn{2}{c}{ Takaran Pupuk kandang Sapi (t/ha) } & \multirow{2}{*}{ Rerata } \\
\cline { 2 - 4 } sekam (t/ha) & 0 & 5 & 10 & \\
\hline 0 & $1,02 \mathrm{~b}$ & $1,59 \mathrm{ab}$ & $1,45 \mathrm{ab}$ & 1,35 \\
5 & $1,89 \mathrm{ab}$ & $1,73 \mathrm{ab}$ & $1,55 \mathrm{ab}$ & 1,72 \\
10 & $2,28 \mathrm{a}$ & $1,60 \mathrm{ab}$ & $2,34 \mathrm{a}$ & 2,07 \\
\hline Rerata & 1,73 & 1,64 & 1,78 & $(+)$ \\
\hline
\end{tabular}

Keterangan: Angka yang diikuti dengan huruf yang sama pada kolom atau baris yang sama tidak berbeda nyata menurut uji Tukey $\alpha 5 \%$. (+): Terjadi interaksi antara faktor 


\subsection{Berat Kering Biji Per Tanaman}

Hasil sidik ragam (Anova) menunjukan bahwa tidak terjadi pengaruh interaksi antara takaran arang sekam dan pupuk kandang sapi terhadap berat kering biji per tanaman. Selanjutnya hasil uji menunjukkan bahwa padaada beda nyata antar tiap perlakuan.

Tabel 12. Berat kering biji per tanaman $(\mathrm{g})$

\begin{tabular}{ccccc}
\hline Takaran Arang & \multicolumn{2}{c}{ Takaran Pupuk kandang Sapi (t/ha) } & \multirow{2}{*}{ Rerata } \\
\cline { 2 - 4 } sekam (t/ha) & 0 & 5 & 10 & \\
\hline 0 & 0,65 & 1,04 & 1,20 & $0,97 \mathrm{~b}$ \\
5 & 1,21 & 1,51 & 1,24 & $1,32 \mathrm{a}$ \\
10 & 1,42 & 1,39 & 2,07 & $1,63 \mathrm{a}$ \\
\hline Rerata & $1,09 \mathrm{~b}$ & $1,31 \mathrm{ab}$ & $1,51 \mathrm{a}$ & $(-)$
\end{tabular}

Keterangan: Angka yang diikuti dengan huruf yang sama pada kolom atau baris yang sama tidak berbeda nyata menurut uji Tukey $\alpha 5 \%$. (-): Tidak terjadi interaksi antara faktor

\subsection{Berat Segar Akar}

Hasil sidik ragam (Anova) menunjukan bahwa terjadi interaksi antara takaran arang sekam dan pupuk kandang sapi terhadap berat segar akar. Hasil uji lanjut pada pot perlakuan kombinasi terjadi perbedaan secara nyata.

Tabel 13. Berat segar akar (g/tanaman)

\begin{tabular}{ccccc}
\hline Takaran Arang & \multicolumn{2}{c}{ Takaran Pupuk kandang Sapi (t/ha) } & \multirow{2}{*}{ Rerata } \\
\cline { 2 - 4 } sekam (t/ha) & 0 & 5 & 10 & \\
\hline 0 & $0,57 \mathrm{~b}$ & $2,31 \mathrm{a}$ & $1,76 \mathrm{a}$ & 1,55 \\
5 & $2,32 \mathrm{a}$ & $2,25 \mathrm{a}$ & $1,81 \mathrm{a}$ & 2,13 \\
10 & $2,11 \mathrm{a}$ & $2,01 \mathrm{a}$ & $1,79 \mathrm{a}$ & 1,97 \\
\hline Rerata & 1,67 & 2,19 & 1,79 & $(+)$ \\
\hline
\end{tabular}

Keterangan: Angka yang diikuti dengan huruf yang sama pada kolom atau baris yang sama tidak berbeda nyata menurut uji Tukey $\alpha 5 \%$. (+): Terjadi interaksi antara faktor

\subsection{Berat Kering Akar}

Hasil sidik ragam (Anova) menunjukkan terjadi pengaruh interaksi antara takaran arang sekam dan pupuk kandang sapi terhadapberat kering akar. Hasi uji selanjutnya menunjukkan bahwa pada pot per perlakuan kombinasi terjadi perbedaan secara nyata.

Tabel 14. Berat keringakar (g/tanaman)

\begin{tabular}{ccccc} 
Takaran Arang & \multicolumn{2}{c}{ Takaran Pupuk kandang Sapi (t/ha) } & \multirow{2}{*}{ Rerata } \\
\cline { 2 - 4 } sekam (t/ha) & 0 & 5 & 10 & \\
\hline 0 & $0,30 \mathrm{~b}$ & $0,85 \mathrm{a}$ & $0,70 \mathrm{ab}$ & 0,62 \\
5 & $0,81 \mathrm{a}$ & $0,80 \mathrm{a}$ & $0,67 \mathrm{ab}$ & 0,76 \\
10 & $0,80 \mathrm{a}$ & $0,68 \mathrm{ab}$ & $0,60 \mathrm{ab}$ & 0,70 \\
\hline Rerata & 0,64 & 0,78 & 0,66 & $(+)$
\end{tabular}

Keterangan: Angka yang diikuti dengan huruf yang sama pada kolom atau baris yang sama tidak berbeda nyata menurut uji Tukey $\alpha 5 \%$. (+): Terjadi interaksi antara faktor.

\subsection{Berat Segar Berangkasan}

Hasil sidik ragam (Anova) menunjukan bahwa terjadi pengaruh interaks antara takaran arang sekam dan pupuk kandang sapi terhadap berat segar berangkasan. Hasil uji selanjutnya menunjukkan bahwa pada pot perlakuan kombinasi ada beda nyata.

Tabel 15. Berat segar berangkasan (g/tanaman)

\begin{tabular}{ccccc}
\hline Takaran Arang & \multicolumn{2}{c}{ Takaran Pupuk kandang Sapi (t/ha) } & \multirow{2}{*}{ Rerata } \\
\cline { 2 - 4 } sekam (t/ha) & 0 & 5 & 10 & \\
\hline 0 & $5,86 \mathrm{~b}$ & $21,25 \mathrm{a}$ & $20,01 \mathrm{a}$ & 15,71 \\
5 & $18,81 \mathrm{a}$ & $21,76 \mathrm{a}$ & $20,33 \mathrm{a}$ & 20,30 \\
10 & $24,63 \mathrm{a}$ & $18,35 \mathrm{a}$ & $18,80 \mathrm{a}$ & 20,59 \\
\hline Rerata & 16,43 & 20,45 & 19,71 & $(+)$ \\
\hline
\end{tabular}

Keterangan: Angka yang diikuti dengan huruf yang sama pada kolom atau baris yang sama tidak berbeda nyata menurut uji Tukey $\alpha 5 \%$. (+): Terjadi interaksi antara faktor

\subsection{Berat Kering Berangkasan}

Hasil sidik ragam (Anova) menunjukan bahwa terjadi pengaruh interaksi antara takaran arang sekam dan pupuk kandang sapi terhadap berat segar berangkasan. Hasil uji selanjutnya dapat dilihat bahwa pada pot perlakuan kombinasi terjadi perbedaan seacara nyata.

Tabel 16. Berat kering berangkasan (g/tanaman)

\begin{tabular}{ccccc}
\hline Takaran Arang & \multicolumn{2}{c}{ Takaran Pupuk kandang Sapi (t/ha) } & \multirow{2}{*}{ Rerata } \\
\cline { 2 - 3 } sekam (t/ha) & 0 & 5 & 10 & \\
\hline 0 & $2,25 \mathrm{c}$ & $13,81 \mathrm{ab}$ & $13,81 \mathrm{ab}$ & 9,96 \\
5 & $12,79 \mathrm{ab}$ & $11,35 \mathrm{ab}$ & $10,43 \mathrm{abc}$ & 11,52 \\
10 & $18,64 \mathrm{a}$ & $12,98 \mathrm{ab}$ & $9,59 \mathrm{cb}$ & 13,74 \\
\hline Rerata & 11,23 & 12,71 & 11,28 & $(+)$
\end{tabular}

Keterangan: Angka yang diikuti dengan huruf yang sama pada kolom atau baris yang sama tidak berbeda nyata menurut uji Tukey $\alpha$ 5\%. (+): Terjadi interaksi antara faktor

\subsection{Indeks Panen}

Hasil sidik ragam (Anova) menunjukan bahwa tidak terjadi pengaruh interaksi antara takaran arang sekam dan pupuk kandang sapi terhadap indeks panen. Hasil uji selanjutnya dapat dilihat bahwa ada beda nyata antar perlakuan.

\begin{tabular}{ccccc} 
Tabel 17. Indeks panen & \multicolumn{2}{l}{} \\
\hline Takaran Arang & \multicolumn{2}{l}{ Takaran Pupuk kandang Sapi (t/ha) } & \multirow{2}{*}{ Rerata } \\
\cline { 2 - 4 } sekam (t/ha) & 0 & 5 & 10 & \\
\hline 0 & 7,45 & 6,73 & 8,39 & $7,52 \mathrm{~b}$ \\
5 & 8,45 & 11,98 & 10,57 & $10,33 \mathrm{ab}$ \\
10 & 6,91 & 9,47 & 16,78 & $11,06 \mathrm{~b}$ \\
\hline Rerata & $7,60 \mathrm{~b}$ & $9,40 \mathrm{ab}$ & $11,91 \mathrm{a}$ & $(-)$ \\
\hline
\end{tabular}

Keterangan: Angka yang diikuti dengan huruf yang sama pada kolom atau baris yang sama tidak berbeda nyata menurut uji Tukey $\alpha 5 \%$. (-): Tidak terjadi interaksi antara faktor

\subsection{Pembahasan}

Penanaman kacang hijau pada awal musim hujan umumnya tidak memberikan hasil yang baik. Namun dalam penelitian ini yang menggunakan media pot dengan komposisi media berupa campuran tanah, pupuk kendang dan arang sekam, ternyata dapat meningkatkan pertumbuhan dan hasil tanaman kacang hijau. Sedangkan pada pot yang tidak diberi arang sekam dan pupuk kendang menunjukkan bahwa pertumbuhan dan hasil kacang hijau rendah. Hal ini dapat dilihat pada data hasil pengamatan baik pada parameter pertumbuhan maupun hasil.

Peningkatan pertumbuhan dan hasil tanaman sangat tergantung pada dukungan kondisi lingkungan. Kondisi lingkungan yang baik memungkinkan pertumbuhan dan perkembangan akar semakin baik sebagai dampak dari pemberian arang sekam dan pupuk kandang 5-10t/ha, dimana akar tanaman lebih panjang, berkisar antara 27,32-31,25 cm dan berat segar akar 2,01-2,25 g. Perakaran yang baik ini dapat menyerap air dan unsur hara dengan maksimal sehingga mampu menunjang pertumbuhan tanaman kacang hijau. Pada umur 42 HST tinggi tanaman mencapai 32,56-37,30 cm, jumlah daun 27,33-29,33 helai Karena pemberian pupuk kendang dan arang sekam 5-10 t/ha. Pada akhirnya tanaman kacang hijau yang tumbuh dengan baik tersebut dapat memberikan hasil yang tinggi, dimana jumlah polong lebih banyak $(4,33-5,88 \mathrm{~cm})$, jumlah biji per polong terbanyak $(8,34$ biji), berat kering biji tertinggi pada perlakuan $5-10$ t/ha pupuk kandang $(1,31-1,51 \mathrm{~g} / \mathrm{tan}$.) dan pada perlakuan arang 5-10 t/ha $(1,32$ $1,63 \mathrm{~g} / \mathrm{tan})$. Namun berdasarkan perhitungan indeks panen, ternyata pengaruh takaran arang sekam $5 \mathrm{t} /$ ha dan pupuk kandang sapi $5 \mathrm{t} /$ ha lebih tinggi daripada takaran lainnya. Dengan demikian, budidaya kacang hijau yang menggunakan arang sekam dan pupuk kendang dengan takaran $5 \mathrm{t} / \mathrm{ha}$ dapat memperbaiki kondisi tanah dan dapat meningkatkan pertumbuhan dan hasil tanaman.

\section{Simpulan}

Pertumbuhan kacang hijau yang diberi perlakuan arang sekam dan pupuk kandang sapi jauh lebih baik dibandingkan yang tidak diberi perlakuan arang sekam dan pupuk kandang sapi. Hasil tertinggi kacang hijau diperoleh dari pemberian arang sekam dan pupuk kandang sapi 5 t/ha.

\section{Pustaka}

BPS NTT. 2015. Berita Resmi Statistik. BPS Provinsi Nusa Tenggara Timur. No. 08/03/53/Th.XVIII, 2 Maret 2015

Direktorat Budidaya Aneka Kacang dan Umbi, Ditjen Tanaman Pangan. 2012 Pedoman Teknis Pengelolaan Produksi Kacang Tanah, Kacang Hijau dan Aneka Kacang.

Duke, J.A, 1991. Legumens Of World Economic Importance. Plenum Press, New York and London. Hal : 294

Fahmi, I. Z. 2013. Media Tanam Hidroponik Dari Arang Sekam. Balai Besar Perbenihan dan Proteksi Tanaman Perkebunan. Surabaya.

Gomez, K. A. dan A. A. Gomes. 1995. Prosedur Statistik untuk Penelitian Pertanian. Edisi ke 2. Jakarta:UI Press.

Hartatik, W. dan L.R. Widowati. 2010. Pupuk Kandang. http://www.balittanah.litbang.deptan.go.id. Diakses tanggal 10 Oktober 2015

Lingga, P. 1991. Jenis dan Kandungan Hara pada Beberapa Kotoran Ternak Pusat Pelatihan Pertanian dan Pedesaan Swadaya (P4S) ANTANAN. Bogor.

Prihmantoro, H. 2003. Memupuk Tanaman Sayur. Penebar Swadaya. Jakarta

Soemeinaboedhy, N. dan R. S. Tejowulan. 2007. Pemanfaatan Beberapa Macam Arang Sebagai Sumber Unsur Hara P dan K Serta Sebagai Pembenah Tanah. Jurusan Ilmu Tanah Fakultas Pertanian Universitas Mataram. Agroteksos. 17(2): 114-122

Sunantara, I.M.M. 2000. Teknik produksi benih kacang hijau. No. Agdex: 142/35. No. Seri: 03/Tanaman/2000/September 2000. Instalasi Penelitian dan Pengkajian TeknologiPertanian Denpasar Bali.

Syahid, A.Pituati, G., Kresnatita, S. 2013. Pemanfaatan Arang Sekam Padi dan Pupuk Kandang untuk Meningkatkan Pertumbuhan dan Hasil Tanaman Segau pada Tanah Gambut. Jurnal Agri Peat Fakultas Pertanian Universitas Palangka Raya Kalimantan Tengah. Diakses pada tanggal 27 Oktober 2015 pada alamat: https://jurnalagriepat.wordpress.com. 